\title{
The Exploration of the Concept and Practice of Individualized English Teaching in Contemporary Chinese Context
}

\author{
Liwen Yin ${ }^{1, a}$ \\ ${ }^{1}$ Foreign Languages School of Hebei North University, Zhangjiakou city of Hebei province 075000 , \\ Peoples R China. \\ atomatobaby1028@163.com
}

Keywords: Chinese context; Individualized English; Teaching ideas; Practice

\begin{abstract}
English is an important course to cultivate students' Comprehensive English skills. It aims at improving students' comprehensive language knowledge level and practical application ability and improving their comprehensive English level. Through effective classroom teaching, students can improve their grammatical rhetoric, reading comprehension and writing ability. With the continuous development of our society, the application of English is becoming more and more extensive. This paper analyzes individualized English and individualized English Teaching in Chinese context, and then introduces specific teaching practice.
\end{abstract}

With the globalization of the economy and the universality of the Internet, English is becoming more and more important as a tool for acquiring and communicating information. This requires teachers to have more efficient means of teaching English, and require students to integrate with the world in the teaching environment. However, English Teaching in China is not very optimistic now. Although educators have been trying to change the inappropriate teaching and teaching methods, and have made great achievements, the improvement of English teaching still needs a long and hard road. English is a foreign language. In the context of Chinese, English teaching not only helps students learn English by means of Chinese context, but also helps students build an English language environment and individualized English teaching.

\section{Individualized English Teaching in Chinese Context}

With the continuous development of society, the culture of our country is also spreading out. While we are actively carrying out English teaching, many foreigners are also actively learning Chinese. Many foreigners are very interested in Chinese culture, and the language of China is more so. Foreigners are actively learning Chinese, and we are actively teaching foreign languages. A considerable number of students are less enthusiastic about Chinese than English. This makes the teaching fever of English and Chinese form a great gap in the teaching system of our country. This leads many of us to think that our teaching has entered a very dangerous stage, and the Chinese language has been gradually neglected. The teaching of English has been overemphasized. In fact, this is a rather extreme idea. With the development of the times, the demand for English talents is also increasing. However, the current teaching system in China is hard to cultivate high-quality English talents. The lack of English talents is the motive force that leads to the excessive promotion of the importance of English Teaching in China. But just raising the importance of English Teaching in people's mind is not enough, because the current English teaching method in China is not able to solve this problem well, but it will be because too much promotion is important to English teaching, but it has an impact on the teaching of Chinese language. Under the new situation, how to solve the problem of the shortage of high-end English talents in China is the best way to reform the existing English teaching and implement individualized English teaching.

\section{Characteristics of English Teaching in Chinese Context}

In our country, English teaching and foreign language teaching are carried out in our country. In the first place, there is a great difference in the environment. In the current social environment, teachers can only help the teaching of English with the help of the Chinese language environment, 
so the way of teaching English is not perfect. The teaching of English should be carried out in the language environment of English so as to achieve its due teaching effect. But in our current teaching system, it is not very realistic to introduce English context into English teaching, because at present, most of our country do not have enough resources to help students build English language environment and help students learn English better. So in China, English teaching should also be carried out in the Chinese language environment, even if such a language environment will hinder English teaching, but the reasonable use of resources around the English Teaching in the Chinese language environment, still can achieve good effect of English teaching. It is difficult to teach English in the Chinese language environment. Under the existing English teaching system in China, the test oriented teaching system has become the main body of the current English teaching mode in China. This kind of English teaching excessively strengthens the students' knowledge of English and ignores the improvement of students' ability to apply English. This is closely related to the lack of English language environment in our current teaching system. This way of teaching can enable students to quickly grasp grammar in English, but in practical English application, such teaching methods do not improve students' practical ability. But it is possible to organize students to teach English through the context of the Chinese language to help English Teaching in the Chinese language environment.

\section{Characteristics of Individualized English Teaching}

With the development of China's society, foreign language talents are constantly increasing in China. Most of these foreign language talents are English, but not all. Because of the unbalanced development of our country, it is not suitable for the promotion of English Teaching in many places. Under such circumstances, our country is currently implementing a diversified development mode, that is to say, encourage the development of many languages, such as French, Japanese, Russian and German. To encourage the development of different foreign language teaching in different regions, this is the outstanding performance of the individualized foreign language policy. This can help our country cultivate diverse talents, enable our universities to cultivate talents more diversified, and cultivate talents in Colleges and universities to diversify. This is of great significance for the teaching of English in China. If we carry out individualized teaching in the current teaching system in our country, this will greatly improve the level of English Teaching in China. English Teaching in different regions can be implemented on the basis of different local teaching environments, for example, in some more economically developed areas, English teaching can help students build English language environment, help students improve their language dialogue ability, and enhance their practical English application ability. But in the remote inland area, under the circumstance of lacking English language environment, we can organize students to watch English movies and help students understand English better through multimedia teaching. Let the students realize that English is not only a subject that needs to be tested, but also a tool to communicate with others.

\section{The Practice of Individualized English Teaching in Chinese Context}

Foreign language teaching in Chinese context is quite different from Chinese language teaching. Chinese language teaching with context as a support can help students learn Chinese better. But the teaching of English in the Chinese language environment is to change the original teaching strategy and formulate the individualized English teaching methods according to the actual situation.

\section{Individualized English Teaching from a Cultural Perspective}

Language can reflect people's thinking activities, different language types will be very intuitive to reflect the characteristics of different nationalities and society. From a specific point of view, language is composed of many different elements, including grammar and words, words and phonetics. In terms of nonverbal behavior and pragmatics, there is a close relationship with semantic returns. Language is a cultural gene in a nation's blood. Language is a part of culture and a reflection of culture. In the process of carrying culture and spreading culture, language contains deep cultural connotation in addition to communication tools. English itself is a language, it is also a culture. Under the system of examination oriented education, English is regarded by students as a tool for examination, not a language and a tool to communicate with others. To really learn the 
language well, it is very important to understand the culture behind the language. Only a real understanding of the culture behind the language can accept the language environment of English and improve its ability to communicate in English. The individualized English teaching should start with the culture and let the students really understand the culture behind English. Changing the old teaching methods, adding English culture teaching elements to English teaching, so that students can enjoy English better and improve the quality of English teaching. The introduction of this language in daily life will make language learning easier. Problems in teaching, for example: What are they What counll'y does each symbol? Come from / sym bolize / represent What are the symbols of? The American Culture Name some and tell US? The reasons. to organize students to appreciate some of the sights of the world or classical music and naturally introduced text: But according to the author of this text, which five things are the symbols, are, and so on, so as to introduce students into teaching content naturally. At the same time. This method can also help students understand the culture behind English and help students to understand English and improve their interest in English learning.

\section{Individualized Teaching through Cultural Differences}

Culture is born in the whole development process of human society. It is a variety of things that all members of society form and co create in their common life and activities, and also includes common behaviors and psychology formed in various activities. From a broad perspective, the culture contains three levels of content, namely, material culture, institutional culture and psychological culture. Among them, material culture belongs to the current culture and is a kind of visible culture. The psychological culture and institutional culture belong to the invisible culture, which are also called the latent culture or the recessive culture. In the process of the continuous progress and development of human society, culture has been formed, including all kinds of spiritual wealth and material wealth. Culture, as a term, is flexible. Culture represents the different ways of thinking and values of different countries and nationalities. It is the natural language used by human communication. Language is everywhere, so it is known that language is included in the culture. Moreover, any language produces and serves the culture that it depends on. And language is a kind of spiritual activity and a social phenomenon. Therefore, language is bound to play an important role in culture. Language, as the carrier of its culture, is transferred from the previous generation to the next generation, that is, cultural heritage. Language is not derived from heredity, but learned from the cultural background. The mapping of language to the external world is not always completely faithful. It will take the brand of its own culture and influence the cognition of the world to the people who hold the language. In general, the close relationship between language and culture is first shown, and language is a symbolic system used to record culture. Secondly, language is a kind of system culture, and it is one of the important components of culture. In addition, there is a situation of mutual influence and restriction between culture and language. Chinese culture is very different from foreign culture. It helps students to understand cultural differences and help students learn English better in Chinese language environment. For example, Pandora 'S Box in teaching, teachers can ask the students the question "Pandora is the first woman in Helenic legend, but who isin Hebrew myths and who is in Chinese? Story?" by these two problems, let students differences between western culture and Western thought of Western culture.

\section{Individualized English Teaching for Different Students}

The main body of English teaching is students, so the content of English teaching should also be made according to the actual situation of the students. However, under the current teaching mechanism, the students' understanding and acceptance of English knowledge are different, which also causes the differences of students' English level. And individualized English teaching requires teachers to organize individualized teaching according to the situation of different students in the course of organizing English teaching. Each student has its own characteristics because of the students' different qualities, different characters and different interests and hobbies. Whether learning better, is the foundation of some poor, are each one has his good points, each man has his limitations. Teachers should not only see the difference, but also pay more attention to the changes in the teaching process. Therefore, when teaching, we should not only consider the similarities 
between students, but also take care of their differences. That is to teach all students and teach students in accordance with their aptitude. To this end, the teaching can not be made "one size fits all". For good students, apart from classroom teaching, but also to arrange some tutoring materials, guide them to self-study, problems they answer, let them to a higher level; for the poor performance of the students, should take the training method of low starting point, small steps, quick feedback and often correct, timely affirmation every bit of their progress, guide them to improve learning methods; let students correct understanding of their teachers, fully grasp the situation, to carry out targeted teaching, and no longer hold incomplete, walk across the board, the traditional teaching way ahead ".

\section{Conclusion}

In the current situation, only the reform of English teaching can be applied to our English teaching resources. In the context of China, individualized English teaching can help students better understand the meaning of English learning for students. Students can improve their English communicative competence and application ability by individualized English teaching. This kind of teaching should be the direction of the current reform of English Teaching in China.

\section{References}

[1] Muhammad Ali Noor, Malik M.A. Khalfan, Tayyab Maqsood. The role of procurement practices in effective implementation of infrastructure projects in Pakistan[J]. International Journal of Managing Projects in Business, 2013, 07(64): 102-110.

[2] Fotopoulos, Christos, Kafetzopoulos, Dimitrios, Gotzamani, Katerina. Critical factors for effective implementation of the HACCP system: a Pareto analysis[J]. EN, 2011, 07(14): 1135-1140.

[3] Weiner Bryan J, Lewis Megan A, Linnan Laura A. Using organization theory to understand the determinants of effective implementation of worksite health promotion programs. [J]. Health Education Research, 2010, 07(12): 242-250.

[4] Christos Fotopoulos, Dimitrios Kafetzopoulos, Katerina Gotzamani. Critical factors for effective implementation of the HACCP system: a Pareto analysis[J]. British Food Journal, 2011, 09(12): 1135-1401.

[5] Evangelos L. Psomas, Christos V. Fotopoulos, Dimitrios P. Kafetzopoulos. Critical factors for effective implementation of ISO 9001 in SME service companies[J]. Managing Service Quality, 2010, 08(09): 205-209.

[6] Farahmand, A.-M.,Ahmadabadi, M.N.,Lucas, C. et al.Interaction of Culture-Based Learning and Cooperative Co-Evolution and its Application to Automatic Behavior-Based System Design[J].IEEE transactions on evolutionary computation: A publication of the IEEE Neural Networks Council,2010,14(1):23-57. 